\title{
KOMPOSISI JENIS DAN KERAPATAN MANGROVE DI PESISIR ARAFURA KABUPATEN MERAUKE PROVINSI PAPUA
}

\author{
Siti masiyah*, Sunarni* \\ *Staf Pengajar FAPERTA Univ. Musamus-Merauka, e-mail: S. Masiyah@yahoo.com
}

\begin{abstract}
ABSTRAK
Penelitian ini dilakukan untuk mengetahui komposisi jenis dan kepadatan mangrove di pesisir laut Arafura, Merauke. Penelitian ini sangat penting dan utama, untuk mempertahankan fungsi dan manfaat hutan mangrove sebagai ekosistem kunci dan penunjang kawasan pesisir laut Arafura. Pelaksanaan penelitian dilakukan pada September- Desember 2014, lokasi dibagi menjadi 3 stasiun, pengambilan data menggunakan metode observasi, transek dan plot ukuran $10 x 10 \mathrm{~m}$. Jenis-jenis mangrove yang ditemukan diidentifikasi, data jumlah individu/ jenis digunakan untuk menghitung kerapatan jenis per luas area, dilanjutkan dengan analisis diskriptif kualitatif. Ekosistem mangrove Pesisir Arafura Kabupaten Merauke di stasiun I. Karang Indah memiliki 14 jenis mangrove dengan katagori padat dan baik (1200 pohon/ha dan penutupan jenis 91.4). Stasiun II. Samkai, memiliki 4 jenis mangrove, Stasiun III Rimba Jaya, memiliki 8 spesies, kedua stasiun ini sama-sama memiliki kreteria rusak. Komposisi spesies dan kepadatan ekosistem mangrove di pesisir ini sangat dipengaruhi oleh degradasi dan eksploitasi ekosistem.
\end{abstract}

Kata Kunci: Komposisi, Kepadatan, Mangrove, Arafura, Merauke

\section{PENDAHULUAN}

Potensi sumberdaya alam di Kabupaten Merauke sangat luas, baik potensi sumberdaya yang dalam proses pemanfaatan maupun potensi untuk pengembangan sumberdaya alam. Potensi sumber daya alam di Kabupaten Merauke sangat tinggi dan beranekaragam, baik potensi SDA Hutan, SDA Sungai, SDA Pantai, dan SDA Laut. Daerah ini terdiri dari perairan laut Arafura sekitar $75.000 \mathrm{~km}^{2}$, perairan umum (sungai dan rawa) sekitar $71.000 \mathrm{~km}^{2}$ dan garis pantai 1.050 $\mathbf{k m}^{2}$ yang membentang dari Sungai Torasi diperbatasan Republik Indonesia dan Papua New Guenia, disebelah Timur sampai pada Sungai Syrest (Data Badan Pusat Statistik Kabupaten Merauke, 2011).

Merauke yang terletak di ujung selatan Papua memiliki ekosistem mangrove yang sangat luas. Menurut data yang dirilis oleh Pemerintah Kabupaten Merauke Tahun 2009,
Kabupaten Merauke memiliki luasan hutan mangrove. 4.672,382 Ha. Ekosistem mangrove sering disebut sebagai hutan payau atau hutan bakau. hutan mangrove adalah tipe hutan yang khas terdapat disepanjang pantai atau muara sungai yang masih dipengaruhi oleh pasang surut air laut (Nontji, 2007). Hutan mangrove mempunyai peranan yang sangat penting, baik dari segi ekologi dan biologi, untuk menunjang kelangsungan berbagai jenis-jenis hewan yang hidup didalamnya. Misalnya ekosistem ini berperan sebagai habitat untuk berbagai jenis ikan-ikan, crustacean dan molusca. Sehingga dikatakan hutan mangrove merupakan ekosistem kunci dan ekosistem penunjang utama kawasan pesisir laut Arafura.

Komposisi jenis dan kerapatan hutan mangrove di kawasan ini belum pernah diteliti, karena itu dilakukan penelitian untuk mengetahui komposisi jenis dan kerapatan hutan 
mangrove di Pesisir Arafura Kabupaten Merauke. Penelitian ini sangat penting untuk konservasi dan vitalisasi ekosistem mangrove sebagai ekosistem kunci dan penunjang keseimbangan kawasa pesisir laut Arafura.

\section{METODE PENELITIAN}

\subsection{Waktu dan Lokasi Penelitian}

Penelitian dilakukan pada bulan September - Desember 2014 di perairan Kabupaten merauke, Propinsi Papua. Pengukuran dan pengambilan sampel dilakukan sekali dalam sebulan pada masing-masing stasiun, kemudian sampel dianalisis di Laboratorium Manajemen sumberdaya Perairan Universitas Musammus. Lokasi sampling dibagi menjadi tiga stasiun untuk mengetahui identifikasi jenis mangrove dan mengetahui kerapatan mangrove. Adapun ketiga stasiun tersebut meliputi: Stasiun 1 di Kelurahan Karang Indah, titik koordinat $S \quad 08^{\circ} 28^{\prime} \quad 20,6^{\prime \prime}$ dan E $140^{\circ}$ $22^{\prime} 17,8^{\prime \prime}$. stasiun ini terletak di bagian muara sungai Maro, lokasi dipilih secara purposive (Gambar 1). Stasiun 2 di Kelurahan Samkai, titik koordinat S. $08^{\circ} 32^{\prime} 26,9^{\prime \prime}$ dan E.140 $24^{\prime} 42,8^{\prime \prime}$. Stasiun ini terletak di pesisir pantai dan aliran kali- kali kecil. Lokasi dipilih secara purposive (Gambar 1).Stasiun 3 di Kelurahan Rimba jaya, titik koordinat $S 08^{\circ} 33^{\prime} 32,9^{\prime \prime}$ dan E $140^{\circ} 25^{\prime} 47,4^{\prime \prime}$. Stasiun ini terletak di pesisir pantai, lokasi ini dipilih secara purposive (Gambar 1).
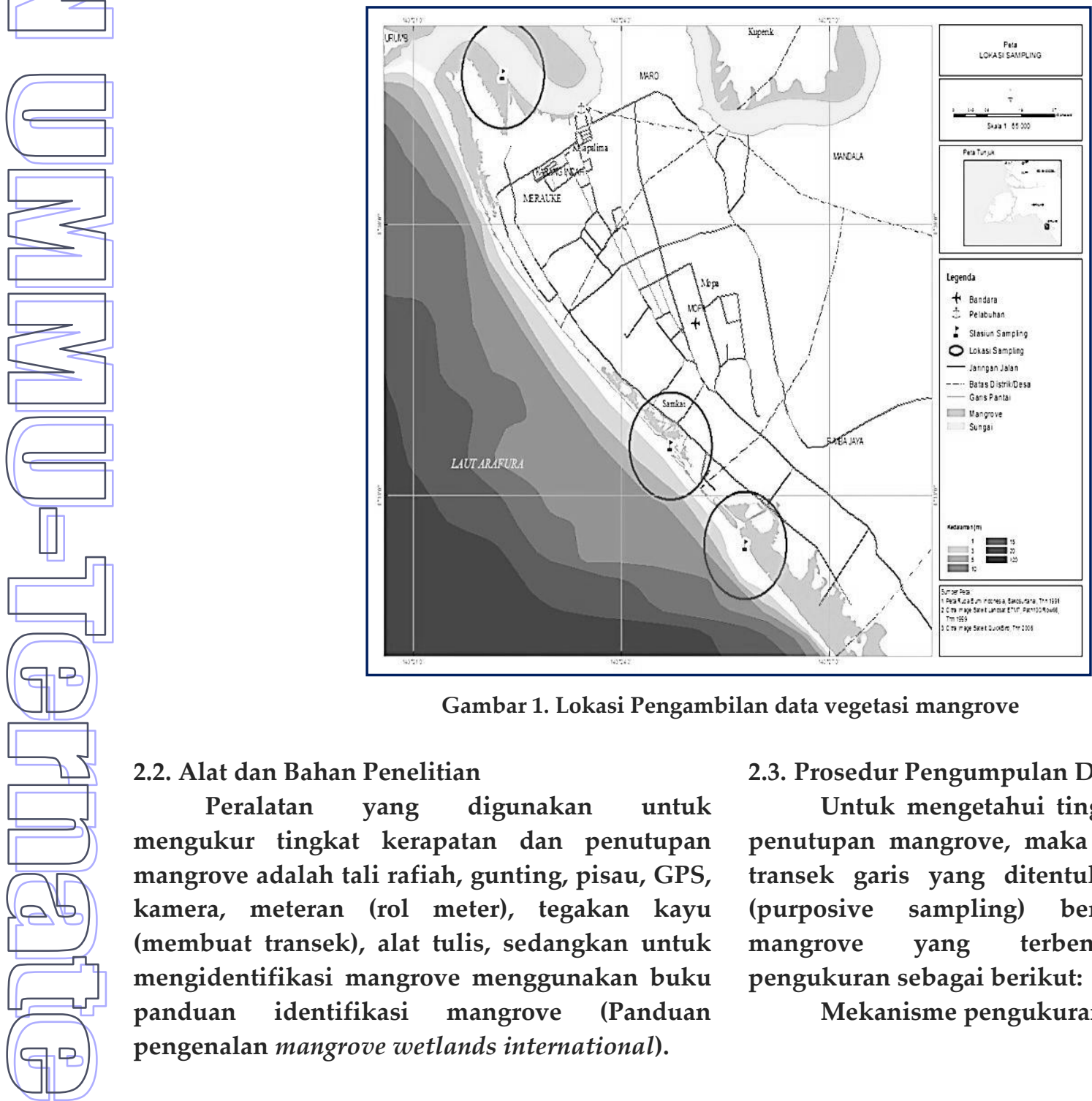

Gambar 1. Lokasi Pengambilan data vegetasi mangrove

2.2. Alat dan Bahan Penelitian

Peralatan yang digunakan untuk mengukur tingkat kerapatan dan penutupan mangrove adalah tali rafiah, gunting, pisau, GPS, kamera, meteran (rol meter), tegakan kayu (membuat transek), alat tulis, sedangkan untuk mengidentifikasi mangrove menggunakan buku panduan identifikasi mangrove (Panduan pengenalan mangrove wetlands international).

\subsection{Prosedur Pengumpulan Data}

Untuk mengetahui tingkat kepadatan dan penutupan mangrove, maka digunakan metode transek garis yang ditentukan secara sengaja (purposive sampling) berdasarkan formasi mangrove yang terbentuk. Mekanisme pengukuran sebagai berikut:

Mekanisme pengukuran sebagai berikut: 
1. Lokasi penelitian di pilih berdasarkan keberadaan vegetasi mangrove.

2. Lokasi penelitian dibagi menjadi 3 stasiun pangamatan.

3. Pada setiap stasiun pengamatan, ditetapkan transek garis dari arah laut kearah darat (tegak lurus garis pantai) sepanjang zonasi hutan mangrove yang terjadi.

4. Sepanjang transek garis, diletakkan secara acak petak - petak contoh (plot) berbentuk bujur sangkar dengan ukuran $10 \times 10$ meter sebanyak10 petak (sesuai dengan kondisi daerah penelitian).

5. Pada setiap petak contoh yang ditentukan, dilakukan identifikasi setiap jenis tumbuhan mangrove yang ada, kemudian dihitung jumlah individu setiap jenis dan ukuran lingkaran batang setiap pohon mangrove setinggi dada (diameter pohon lebih dari $4 \mathrm{~cm}$ dengan tinggi lebih dari $1 \mathrm{~m}$ ).

Tabel 1. Kreteria Baku Kerusakan Mangrove Kepmen PLH No. 201 tahun 2004.

\begin{tabular}{llcc}
\hline & Kriteria & Penutupan $(\%)$ & $\begin{array}{c}\text { Kerapatan } \\
(\text { pohon ha- }\end{array}$ \\
\hline Baik & Sangat padat & $\geq 75$ & $\geq 1500$ \\
& Sedang & $\geq 50-<75$ & $\geq 1000-<1500$ \\
Rusak & Jarang & $<50$ & $<1000$ \\
\hline
\end{tabular}

\subsection{Pengambilan Sampel}

Semua mangrove yang ditemukan dilapang diidentifikasi dengan melihat beberapa bagian bentuk dari mangrove yaitu bentuk daun, bunga, buah, akar dan pohon. Semua bagian pohon mangrove yang dilakukan untuk mengidentifikasi tersebut di lakukan pengambilan gambar dan diambil bagian-bagian pohon yeng belum diketahui identifikasinya kemudian dibawa ke laboratorium untuk dilakukan identifikasi berdasarkan buku panduan identifikasi.

\subsection{Analisa Data}

Analisa data yang dilakukan menggunakan analisa Bengen (2004)

Untuk menentukan nilai kerapatan jenis. Kerapatan jenis merupakan perbandingan antara jenis $\mathbf{i}\left(\mathrm{n}_{\mathrm{i}}\right)$ dengan jumlah luas total area pengambilan contoh (A), dengan formula sebagai berikut :

$$
\mathrm{D}_{\mathrm{i}}=\mathbf{n}_{\mathrm{i}} / \mathrm{A}
$$

Dimana :

$D_{\mathrm{i}}=$ kerapatan jenis ke-i,

$n_{i}=$ jumlah total tegakan jenis ke-i,

A = luas total area pengambilan contoh (luas total petak contoh/plot).

\section{HASIL DAN PEMBAHASAN}

3.1. Diskripsi Daerah Penelitian Karang Indah, Samkai dan Rimba Jaya

Perairan Pantai Karang indah, Samkai dan Rimba Jaya merupakan bagian perairan yang berhadapan langsung dengan laut Arafura. Perairan pantai ini setiap tahunnya banyak menerima suplai air tawar dari perairan darat terutama sungai maro, lepro dan anakan sungai yang ada sekitar pesisir Arafura. Wilayah ini secara administrasi merupakan lingkup wilayah Kabupaten Merauke dengan garis pantai sekitar $3,2 \mathrm{~km}$. Pekerjaan utama masyarakat sekitar pesisir Araura adalah melakukan penangkapan ikan, kepiting dan penggalian pasir.

Kandisi stasiun 1 dengan stasiun yang lain berbeda, stasiun 1 pada kelurahan karang Indah dengan ekosistem mangrove jauh dari pemukiman penduduk, stasiun ini terbelah oleh sungai maro dan kondisi mangrove sebagian sangat alami. Kondisi daerah penelitian dapat dilihat pada lampiran (1-3). Pada stasiun ini banyak dilakukan masyarakat disekitar melakukan pencarian kepiting. Input air dari sungai maro sangat besar, pada saat pasang air dari sungai sampai ekosistem mangrove terendam dan pada saat surut air pada sungai dan sekitar ekosistem mangrove benar-benar kering. 
Kondisi yang sangat fluktuatif menjadikan waktu sampling sangat terbatas.

Sedangkan pada stasiun II Kelurahan Samkai, sangat dekat dengan perkampungan penduduk, daerah ini juga terpengaruh dengan pasang surut. Pengrusakan mangrove mulai tampak dan jarang ditemukan kepiting bakau. pada stasiun III kelurahan Rimba Jaya, kondisi stasiun III sedikit jauh dengan pemukiman penduduk, dimana pada stasiun ini terdapat sungai lepro yang merupakan perbatasan antara Pantai payum dengan Rimba jaya. Kondisi mangrove sudah sedikit mengalami kerusakan dikarenakan aktivitas masyarakat untuk melakukan penggalian Pasir.

Tabel 2. Jenis- jenis Mangrove di Pesisir Arafura

\begin{tabular}{|c|c|c|c|c|}
\hline No & Jenis Mangrove & $\begin{array}{c}\text { Stasiun } 1 \\
\text { (Karang Indah) }\end{array}$ & $\begin{array}{l}\text { Stasiun } 2 \\
\text { (Samkai) }\end{array}$ & $\begin{array}{c}\text { Stasiun } 3 \\
\text { (Rimba Jaya) }\end{array}$ \\
\hline 1 & Avecenia officinalis & $\sqrt{ }$ & & \\
\hline 2 & A. marina & $\sqrt{ }$ & & \\
\hline 3 & A. alba & $\sqrt{ }$ & $\sqrt{ }$ & $\sqrt{ }$ \\
\hline 4 & A. eucalyptifolia & & & $\sqrt{ }$ \\
\hline 5 & Aegialitis annulata & $\sqrt{ }$ & & $\sqrt{ }$ \\
\hline 6 & Aegliceras floridum & & $\sqrt{ }$ & $\sqrt{ }$ \\
\hline 7 & Acanthus abractearus & $\sqrt{ }$ & & \\
\hline 8 & Brugueira cylindrica & $\sqrt{ }$ & & \\
\hline 9 & B. gymnorhiza & $\sqrt{ }$ & & \\
\hline 10 & B. hainessii & $\sqrt{ }$ & & \\
\hline 11 & Ceriop decandra & $\sqrt{ }$ & & \\
\hline 12 & C. tagal & $\sqrt{ }$ & & \\
\hline 13 & Osbornia oktodonta & $\sqrt{ }$ & & \\
\hline 14 & Rhizophora cylindrica & & & $\sqrt{ }$ \\
\hline 15 & R. mukronata & $\sqrt{ }$ & & $\sqrt{ }$ \\
\hline 16 & R. stylosa & $\sqrt{ }$ & $\sqrt{ }$ & $\sqrt{ }$ \\
\hline 17 & Sonneratia alba & $\sqrt{ }$ & $\sqrt{ }$ & $\sqrt{ }$ \\
\hline & Jumlah Jenis/ Statsiun & 14 & 4 & 8 \\
\hline
\end{tabular}

Pada stasiun 1 didapatkan 14 jenis mangrove Dapat dilihat pada (Tabel 2)antara lain: stasiun ini didominasi oleh Rhizophora sp, Avecenia sp, dan Ceriops sp. Dari ketiga jenis tersebut Rhizophora yang paling banyak ditemukan, jenis lebih cocok dengan substrat lumpur dengan suplai air tawar yang cukup. Posisinya lokasi statsiun 3 jauh dengan pemukiman penduduk, serta terletak di muara sungai Maro.

Jumlah jenis mangrove di stasiun II jauh lebih sedikit, hanya 4 jenis saja. Stasiun ini didominasi oleh Avecennia sp dan Aegliceras floridum. Lokasi stasiun II langsung berhadapan dengan laut Arafura, posisinya sangat dekat dengan pemukiman penduduk, sering terjadi penebangan pohon mangrove, penambangan pasir, dan juga pada area tertentu dijadikan sebagai tempatan tambatan kapal.

Stasiun III memiliki 8 jenis mangrove, dimana didominasi oleh Avecennia sp, sedangkan Aegliceras floridum merupakan jenis yang paling jarang dijumpai. Lokasi stasiun ini langsung berhadapan dengan laut Arafura, sedikit jauh dengan pemukiman penduduk, sering terjadi pengambilan pohon mangrove untuk kebutuhan rumah tangga penduduk, dan sering terjadi penambangan pasir oleh masyarakat sekitar.

Adapun gambar jenis mangrove yang terdapat di Pesisir Arafura distrik merauke dapat dilihat pada Gambar 2. 

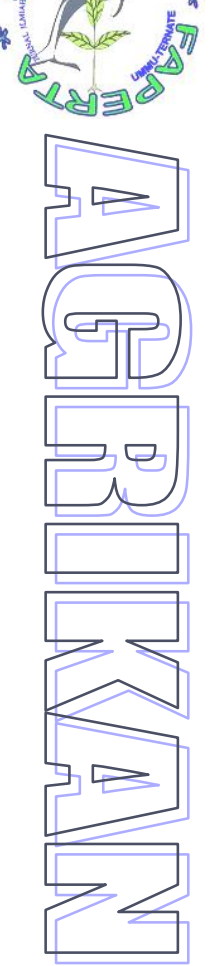

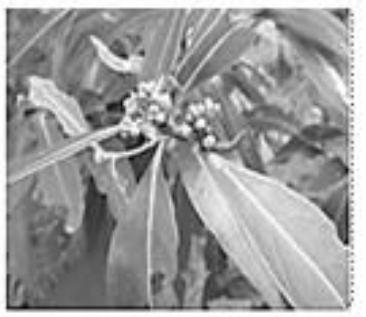

Avicenaing ass

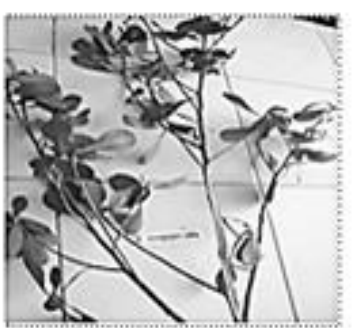

Sonergigess

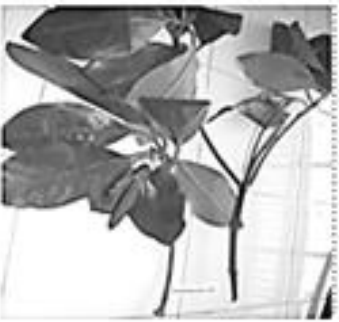

Gitackute corrests

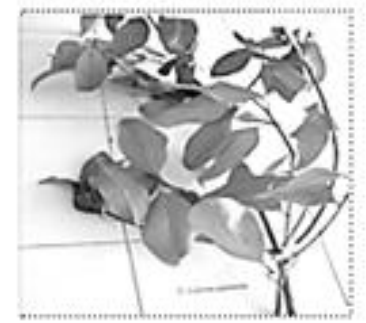

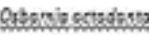

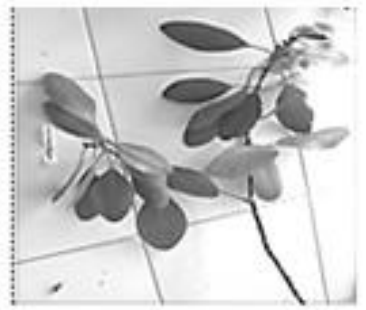

Ceriortasal

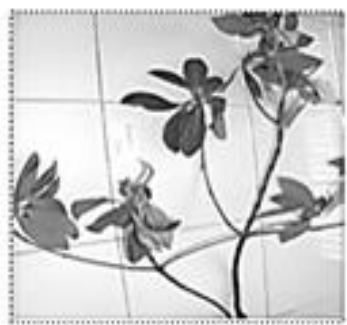

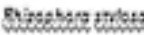

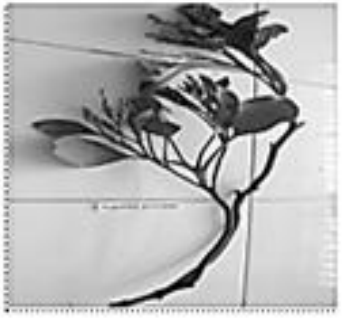

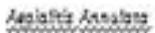

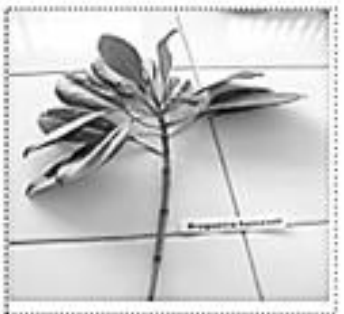

poserighaices:

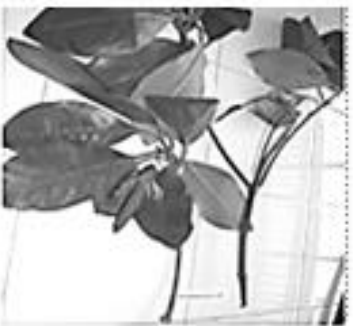

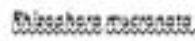

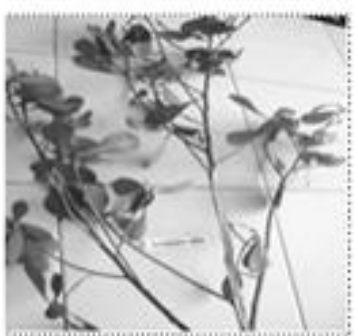

Soneratests

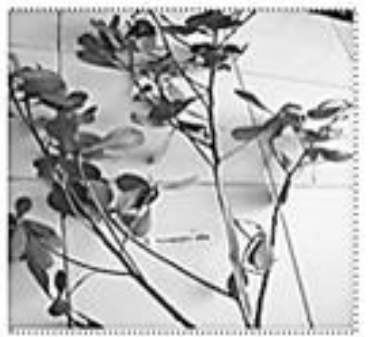

sencrategls

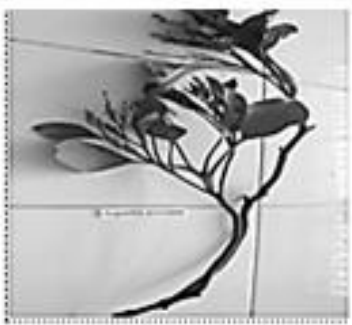

Lesiolit, sualog

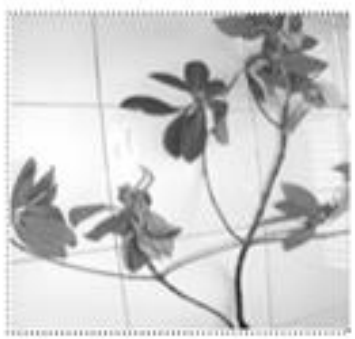

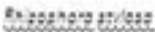

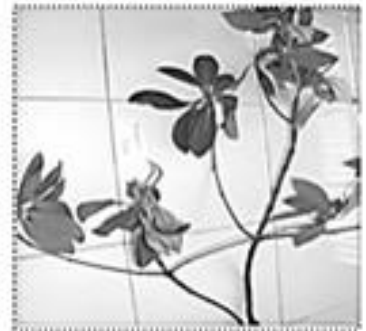

Equathorg entots

Gambar 2. Jenis-jenis mangrove yang terdapat pada stasiun 1 (karang Indah)

Dari hasil penelitian pada stasiun I (karang Indah) didapatkan keanekaragam mangrove yang sangat tinggi dibanding dengan stasiun yang lainnya. Dari 14 jenis mangrove pada stasiun 1 (Karang Indah) banyak didominasi jenis Rhizophora sp, Avicennia sp,dan paling sedikit didapatka jenis Ceriop sp. Hasil penelitian komposisi jenis pada stasiun 1 (Karang Indah).

Hal ini dikarenakan substrat mangrove yang sesuai untuk kelangsungan hidup jenis
Rhizophora sp. Jenis mengrove ini sangat cocok dengan substrat lumpur yang lebih tinggi, suplai air tawar yang cukup. Selain itu daerah yang memiliki genangan yang tinggi pada saat pasang dan surut yang rendah pada saat surut cocok untuk kelangsungan mangrove, ekosistem mangrove yang terdapat Karang Indah yang jauh dengan masyarakat dan terletak didepan sungai Maro serta didalam ekosistem mangrove juga 
ditemukan anakan sungai yang menghubungkan ke muara laut Arafura.

Identifikasi Mangrove Pada Stasiun 2 (Samkai) Pada stasiun II didapatkan 4 Jenis antara lain,

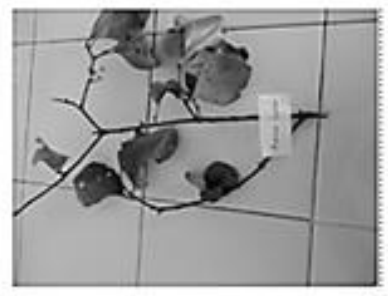

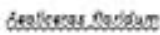

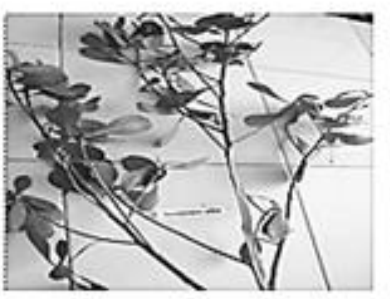

Sasserotis abo

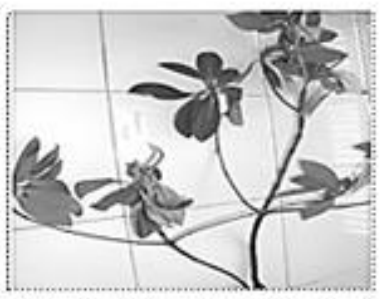

Ritiogiana saiogr

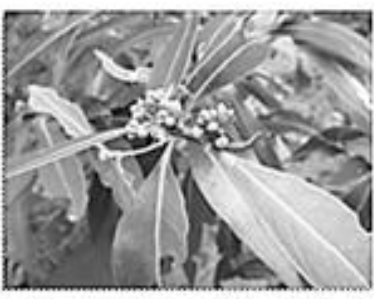

Grisengigaso

Gambar 3. Jenis-jenis mangrove yang didapatkan pada stasiun II

Pada stasiun 2 (Samkai) didapatkan jumlah yang lebih kecil daripada stasiun yang lain stasiun yang lain. Pada stasiun 2 ini banyak didominasi jenis Avicennia sp, sedangkan untuk jumlah yang paling sedikit didominasi oleh Aegliceras floridum. Stasiun 2 (samkai) pada daerah sampling berhadapan langsung dengan laut Arafura yang menjadikan jenis avicennia dapat tumbuh subur. Stasiun 2 juga berdekatan dengan masyarakat dan pada daerah ekosistem mangrove juga didapatkan rumah penduduk. Aktifitasn masyarakat yang melakukan penebangan mangrove sebagai kayu bakar juga berpengaruh pada keberadaan mangrove. Pada stasiun ini juga terjadi pengerukan Pasir dan
Avicennia yang terdapat dibagian depan Pesisir Arafura banyak digunakan sebagai tambatan kapal dalam luasan tidak tentu.

Identifikasi Mangrove Pada Stasiun III ( Rimba Jaya )

Adapun pada stasiun 3 didapatkan 8 jenis mangrove Antara lain Rhizophora cylindrica, Rhizophora mukronata, Rhizophora stylosa, Avicennia alba, Avicennia eucalyptifolia, Sonneratia alba, Aegliceras floridum dan Aegialitis annulata. Gambar hasil identifikasi stasiun III(karang Indah) dapat dilihat pada Gambar 4.
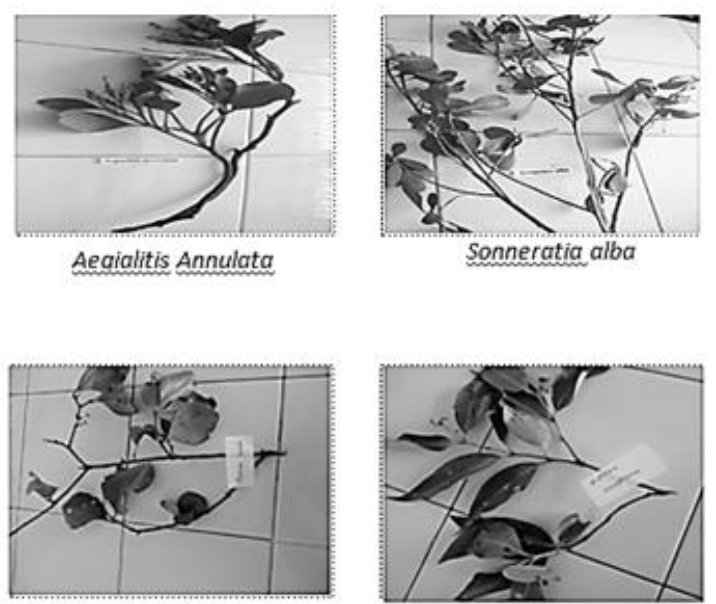

Aegliceras floridum

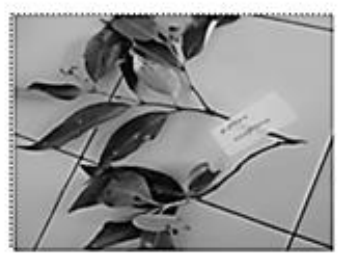

Avicennia eucalvotifolia

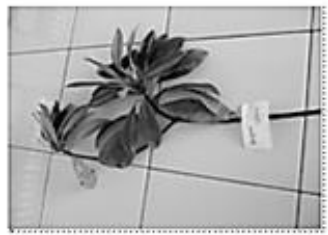

Rhizhooora cylinơrica

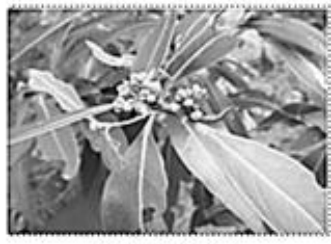

Avicennia alba

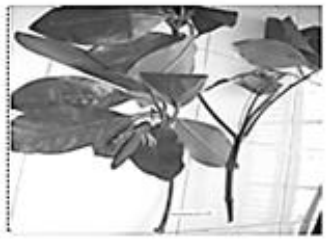

Rhozoohora mucronata

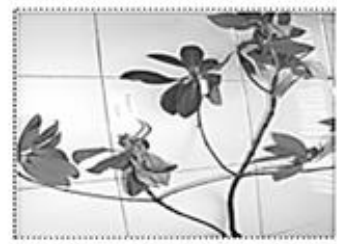

Rhizophora stvlosa

Gambar 4. Jenis-jenis mangrove yang terdapat pada stasiun 3 
Pada stasiun III didapatkan 8 jenis mangrove antara lain: Rhizophora cylindrica, Rhizophora mukronata, Rhizophora stylosa, Avicennia alba, Avicennia eucalyptifolia, Sonneratia alba, Aegliceras floridum dan Aegialitis annulata. Pada Stasiun 3 didapatkan 8 jenis mangrove dengan Avicennia sp yang paling tinggi dan jenis Aegliceras floridum memiliki jumlah yang paling rendah. Avicennia sp yang masih tinggi pada stasiun 3 dikarenakan stasiun 3 juga berhadapan langsung dengan pesisir Arafura, sedikit jauh dengan masyarakat, penebangan mangrove yang terdapat dipesisir Arafura banyak digunakan sebagai kayu bakar dan bahan bangunan. Selain itu pengambilan pasir yang dilakukan oleh masyarakat sekitar. Adapun presentasi pada ketiga stasiun dapat dilihat pada Gambar 5.

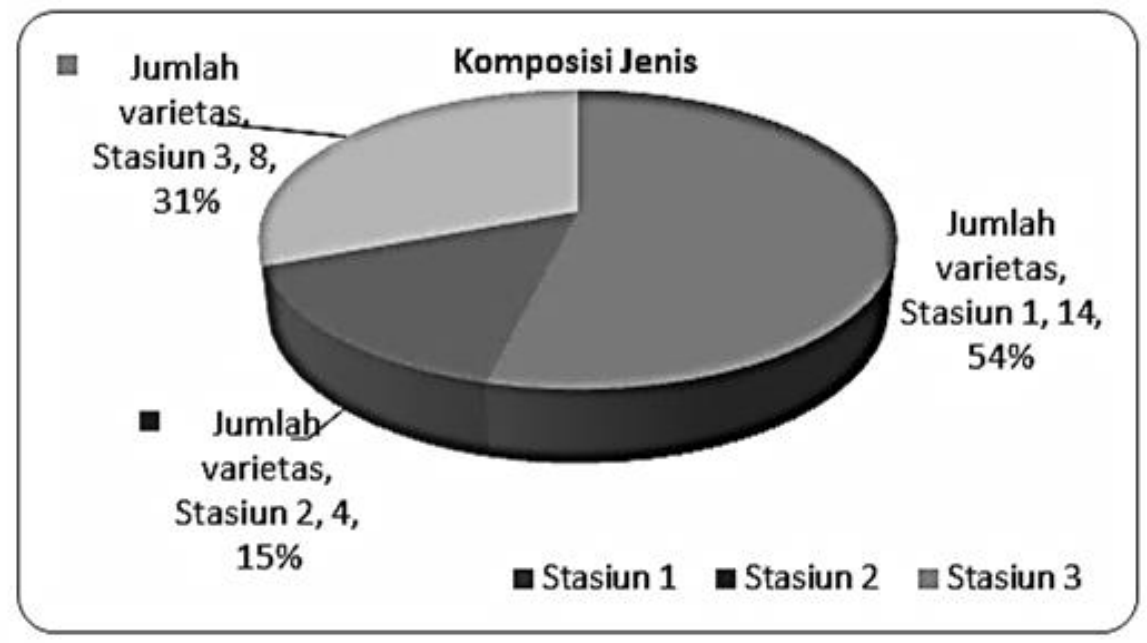

Gambar 5. Jumlah komposisi jenis pada ke 3 Stasiun diPesisir Arafura.

Hasil penelitian dari ketiga stasiun didapatkan (stasiun 1) sebanyak 14 jenis mangrove, Stasiun 2 didapatkan sebanyak 4 Jenis mangrove dan stasiun 3 sebanayak 8 jenis mangrove. Presentasi komposisi jenis yang sangat berbeda pada ke 3 stasiun dimana stasiun $1(54 \%)$, stasiun $2(31 \%)$ dan stasiun $3(15 \%)$. Dikarenakan tingkat pemanfaatan akan kerusakan ekosistem mangrove yang tinggi. Secara keseluruhan hasil penelitian dari komposisi jenis mangrove yang terdapat di Pesisir Arafura terdiri dari 14 spesies antara lain Hasil penelitian ini tidak jauh berbeda dengan penelitian yang dilakukan oleh Mukhlisi, dkk. (2013) di Desa Sidodadi, Kecamatan Padang Cermin Kabupaten Pesawaran, Provinsi Lampung didapatkan 22 jenis mangrove antara lain Avicennia alba Avicenniaceae, Avicennia marina, Barringtonia asiatica, Bruguiera cylindrical, Calophyllum inophyllum, Ceriops tagal, Exoecaria agallocha, Hibiscus tiliaceus,
Lumnitzera littorea, Lumnitzera racemosa, Pandanus tectorius, Pandanus sp, Phempis acidula, Rhizophora apiculata, Rhizophora mucronata, Rhizophora stylosa, Scaveola taccada,Sonneratia alba,Scyphiphora hydrophyllaceae, Terminalia catappa, Thespesia populnea dan Xylocarpus granatum dan menurut Hidayatullah dan Pujiono (2014) yang dilakukan di Kecamatan Boleng Kabupaten Manggarai Barat didapatkan 10 jenis mangrove antara lain Ceriops tagal, Rhizophora apiculata, Bruguiera parviflora, Bruguiera sexangula, Bruguiera gymnorrhiza, Rhizophora mucronata, Phemphis acidula Forst, Xylocarpus granatum, Acrosthicum aureum dan Derris trifoliata Lour dan Penelitian yang dilakukan oleh Antonius de Jesus (2012) yang dilakukan di Perbatasan kota Diladan Distrik Liquisa Timor leste dari hasil penelitian didapatkan 4 jenis mangrove Soneratia Alba, Rhizophora appiculata, Rhizophora Mucronata, Brugueira cylindrical. Perbedaan komposisi jenis 
dari setiap daerah sangat dipengaruhi oleh kondisi fisika, kimia, oceanografi yang mempengaruhi kelangsungan hidup mangrove. Menurut Nontji (2007) bahwa setiap perairan mempunyai sifat-sifat yang berbeda dalam struktur geografi, sifat musim hujan dan kemarau, serta pola siklus air. Oleh sebab itu pertumbuhan organisme yang hidup didalamnya akan mempunyai bentuk dan ukuran yang berbeda. Selain itu campur tangan manusia yang cenderung mengeksploitasi mangrove dimana mangrove memiliki peranan dan manfaat yang sangat penting baik secara biologi, ekologi maupun ekonomi.

3.2. Kerapatan Jenis pada Stasiun 1(karang Indah), II (Samkai) dan III (Rimba Jaya)

Hasil penelitian didapatkan kerapatan jenis, pada ke tiga ekosistem berbeda. Hasil Penelitian Kerapatan jenis mangrove pada stasiun 1 (karang Indah), stasiun II dan stasiun III dapat dilihat pada Tabel 3 dibawah ini

Tabel 3. Kerapatan jenis dan penutupan jenis pada Stasiun I, II, dan III

\begin{tabular}{clccc}
\hline \multirow{2}{*}{ Stasiun } & \multicolumn{1}{c}{ Jenis mangrove } & Kerapatan pohon ha-1 & \multicolumn{2}{c}{ Kriteria } \\
\hline I & Rhizophora sp & 1200 & sedang & Baik \\
& Brugueira sp & 150 & Jarang & Rusak \\
& Sonneratia alba & 100 & Jarang & Rusak \\
& Aegialitis annulata & 25 & Jarang & Rusak \\
& Osbornia otodonta & 21 & Jarang & Rusak \\
& Ceriop sp & 20 & Jarang & Rusak \\
& Avicennia sp & 272 & Jarang & Rusak \\
II & Avicennia sp & 884 & Jarang & Rusak \\
& Sonneratia alba & 189 & Jarang & Rusak \\
& Aegliceras floridum & 11 & Jarang & Rusak \\
& Rhizophora sp & 126 & Jarang & Rusak \\
III & Rhizophora sp & 323 & Jarang & Rusak \\
& Avicennia sp & 877 & Jarang & Rusak \\
& Aegliceras floridum & 6 & Jarang & Rusak \\
& Sonneratia $s p$ & 57 & Jarang & Rusak \\
& Aegialitis annulata & 52 & Jarang & Rusak \\
\hline
\end{tabular}

Hasil penelitian didapatkan pada stasiun I (karang Indah) pada jenis Rhizophora $s p$ memiliki nilai kerapatan yang tinggi yaitu 1200 pohon/ha dan penutupan jenis 91.4 (perhitungan kerapatan dan luas penutupan jenis dapat dilihat pada lampiran 4) sehingga menurut UU no. 201 tahun 2004 masuk dalam criteria baik dan sangat padat. Kemudian pada jenis Ceriop sp didapatkan nilai kerapatan yang sangat kecil dan termasuk dalam criteria jarang dan rusak. Pada stasiun II (Samkai) nilai kerapatan dan penutupan jenis mangrove pada semua jenis masuk dalam kriteria jarang dan rusak. Kemudian pada stasiun III (Rimba jaya) didapatkan kerapatan dan penutupan jenis mangrove masuk dalam criteria jarang dan rusak. Kerusakan mangrove pada ke tiga stasiun disebabkan adanya penebangan mangrove dan penggalian pasir yang dilakukan oleh masyarakat setempat selain itu juga banyak ditemukan anakan mangrove. Hasil Penelitian ini tidak jauh berbeda dengan hasil penelitian Hidayatullah dan Pujiono (2014) yang dilakukan di Kecamatan Boleng Kabupaten Manggarai Barat didapatkan kerapatan jenis berkisar antara $100-1300$ pohon/ ha. Sedangkan hasil Penelitian Menurut Antonius de Jesus (2012) yang dilakukan di Perbatasan kota Diladan Distrik Liquisa Timor leste dari hasil penelitian didapatkan kerapatan berkisar antara 0 - 969 pohon/ha. Hasil dari beberapa penelitian diatas tidak jauh berbeda dengan yang terdapat di pesisir Arafura Kabupaten Merauke dimana dengan kerapatan yang sangat rendah Masuk dalam katerogi mangrove yang rusak. 


\section{PENUTUP}

4.1. Kesimpulan

Vegetasi mangrove dari penelitian yang dilakukan di Pesisir Arafura Kabpaten Merauke dengan mengambil 3 kelurahan yang merupakan stasiun 1 (karang Indah),Stasiun II (Samkai) dan Stasiun III (Rimba Jaya). Secara Keseluruhan Pesisir Arafura didapatkan 14 Jenis Mangrove Rhizophora mukronata, Sonneratia alba, Rhizophora stylosa, brugueira hainessii, Brugueira gymnorrhiza, Ceriop decandra, Avicennia officinalis, Avicennia marina, Bruguiera cylindrical, Ceriop tegal, Avicennia alba, Aegialitis annulata, dan Osbornia oktodonta.
Kerapatan pada Ketiga stasiun berkisar antara 6 1200pohon/ha pada stasiun 1 masuk dalam kategori padat dan baik sedangkan pada stasiun II dan III masuk dalam Criteria Rusak.

\subsection{Saran}

Saran yang bisa disampaikan didalam penelitian ini antara lain:

1. Perlu adanya penelitian lanjuan tentang Indeks nilai Penting (INP) pada ekosistem mangrove di Kabupaten Merauke.

2. Perlu penelitian Potensi mangrove di Kabupaten Merauke dalam pengelolaan mengrove

\section{DAFTAR PUSTAKA}

Anonim, 2011. Badan Pusat Statistik, Kabupaten Merauke In Figures. Kabupaten Merauke.

Anonim, 2009. Laporan Tahunan Dinas Kelautan dan Perikanan Kabupaten Merauke

Anonim, 2006. Buku 1 Potret Sumberdaya Kawasan Laut Arafura dan Laut Timor Menuju Pembangunan Berkelanjutan. Forum Pakar Laut Arafura dan Laut Timor.

Antonio de Jesus, 2012. Kondisi ekosistim mangrove di sub district Liquisa Timor-LesteMangrove ecosystems condition in Liquisa sub district Timor-Leste. Jurnal ISSN 2089-7790.

Bengen, D. G. 2004. Pedoman teknis: Pengenalan dan pengelolaan ekosistem mangrove. PKSPL-IPB. Bogor.

Bengen. D. G. dan I. M. Dutton 2004. Interaction: mangroves, fisheries and forestry management in Indonesia. H. 632-653. Dalam Northcote. T. G. dan Hartman (Ed),Worldwide watershed interaction and management. Blackwell science.. Oxford. UK.)

Hartini, S., G. B. Saputro, M. Yulianto, Suprajaka. 2010. Assessing the Used of Remotely Sensed Data for Mapping Mangroves Indonesia. Selected Topics in Power Systems and Remote Sensing. In 6th Wseas International Conference on Remote Sensing (Remote'10), Iwate Prefectural University, Japan. October 4-6, 2010; pp. 210-215

Hidayatullah M dan Pujiono Eko. 2014. Struktur dan komposisi jenis Hutan Mangrove di Golo Sepang Kecamatan Boleng Kabupaten Manggarai Barat. Jurna Peneliti pada balai PenelitianKehutan Kupang.

Kusmana, C. 2005. Manajemen hutan mangrove Indonesia. Lab Ekologi Hutan. Jurusan Manajemen Hutan, Fakultas Kehutanan, IPB. Bogor.

Menteri Negara Lingkungan Hidup Republik Indonesia (2004) Keputusan Menteri Negara Lingkungan Hidup Republik Indonesia Nomor. 201 Tahun 2004 tentang Kriteria Baku dan Pedoman Penentuan Kerusakan Mangrove.

Mukhkisi, dkk. (2013). Keanekaragaman Jenis dan Struktur Vegetasi Mangrove di Desa Sidodadi Kecamatan. Prosiding Seminar Pengelolahan Sumberdaya Alam dan Lingkungan Padang Cermin Kabupaten Pesawaran, Provinsi Lampung

Nontji. (2007). Laut Nusantara. Penerbit Djambatan- Jakarta.

Tri Santi Dama Alik, Muh. Ruslan Umar, Dody Priosambodo, 2012. Analisis Vegetasi Mangrove. Di Pesisir Pantai Mara Bomabng - Kabupaten Pinrang. Jurnal Universitas Hasanuddin, Makassar 